\title{
EFEKTIVITAS PEMBELAJARAN KOOPERATIF DALAM MENINGKATKAN AKTIVITAS DAN MOTIVASI BELAJAR MAHASISWA PADA MATAKULIAH STATISTIKA
}

\author{
Ribka Kariani Br. Sembiring \\ Program Studi Pendidikan Matematika Universitas Katolik Santo Thomas \\ ribkakariani@gmail.com
}

\begin{abstract}
This study aims to find out what cooperative learning method is most effective in improving students' activity and motivation in Statistics subject. This research is a Classroom Action Research (PTK). The subjects of this study are the 5th semester students of PGSD Study Program with total number 35 students. Instruments used consist of: (1) Observation sheet of learning implementation; (2) Observation sheet of students' activity in learning with assessment on students' oral activities, visual activities, listening activities, writing activities and emotional activities; (3) Observation sheets of group effectiveness with assessment on the efficiency aspects of problem solving and member participation; (4) Questionnaire of motivation to find out to which extent the learning can improve student's motivation which is seen from the students perception of their satisfaction in learning. The research results show that when PBM learning model is used in cycle 1 and Jigsaw learning model is used in cycle 2, Jigsaw is better than PBM learning model.
\end{abstract}

Keywords: Problem-based learning model, Jigsaw Learning Model, activity and learning motivation.

\begin{abstract}
Abstrak. Penelitian ini bertujuan untuk mengetahui mana metode pembelajaran kooperatif yang paling efektif dalam meningkatkan aktivitas dan motivasi belajar mahasiswa pada Matakuliah Statistika. Penelitian ini merupakan Penelitian Tindakan Kelas (PTK). Subjek penelitian ini adalah mahasiswa Prodi PGSD semester 5 yang mengambil mata kuliah Statistika sejumlah 35 mahasiswa. Instrumen yang digunakan terdiri dari: (1) Lembar observasi keterlaksanaan pembelajaran; (2) Lembar observasi aktivitas mahasiswa dalam pembelajaran dengan penilaian aspek oral activities, visual activities, listening activities, writing activities dan emotional activities; (3) Lembar observasi efektivitas kelompok dengan penilaian pada aspek efisiensi pemecahan masalah dan partisipasi anggota; (4) angket motivasi untuk mengetahui sejauh mana pembelajaran mampu meningkatkan motivasi belajar mahasiswa, dilihat dari persepsi mahasiswa dengan aspek yang dikaji kenyamanan dan kepuasan mahasiswa dalam pembelajaran. Hasil penelitian menunjukkan bahwa ketika model Pembelajaran PBM digunakan pada siklus 1 dan model pembelajaran Jigsaw di gunakan pada siklus ke-2 secara keseluruhan jigsaw lebih baik dari pada model pembelajaran PBM.
\end{abstract}

Kata Kunci: Model Pembelajaran Berbasis Masalah, Model Pembelajaran Jigsaw, Aktivitas dan Motivasi Belajar.

\section{PENDAHULUAN}

Pembelajaran pada hakekatnya adalah proses interaksi antara peserta didik dengan lingkungannya, sehingga terjadi perubahan perilaku ke arah yang lebih baik. Hal ini mengindikasikan bahwa proses pembelajaran yang baik akan berdampak baik pada produk atau hasil dari pembelajaran tersebut. Proses pembelajaran tidak terlepas dari peran pendidik dan perseta didik. Komunikasi yang lancar antar keduanya akan membuat pembelajaran lebih hidup dan menarik. Salah satu hal yang berpengaruh pada proses pembelajaran adalah aktifitas belajar peserta didik.

Aktivitas belajar peserta didik adalah aktivitas yang bersifat fisik ataupun mental (Sardiman, 2005:96). Aktivitas belajar adalah serangkaian kegiatan fisik atau jasmani maupun mental atau rohani yang saling berkaitan sehingga tercipta belajar yang optimal. Dalam aktivitas belajar ini peserta didik haruslah aktif mendominasi dalam mengikuti 
proses belajar mengajar sehingga mengembangkan potensi yang ada pada dirinya. Dengan kata lain dalam beraktivitas peserta didik tidak hanya mendengarkan dan mencatat seperti yang dijumpai di sekolah-sekolah yang melakukan pembelajaran secara konvensional.

Menurut Nasution (2000:89), aktivitas belajar adalah aktivitas yang bersifat jasmani ataupun rohani. Dalam proses pembelajaran, kedua aktivitas tersebut harus selalu terkait. Seorang peserta didik akan berpikir selama ia berbuat, tanpa perbuatan maka peserta didik tidak berfikir. Oleh karena itu agar peserta didik aktif berfikir maka peserta didik harus diberi kesempatan untuk berbuat atau beraktivitas.

Motivasi adalah daya penggerak atau pendorong untuk melakukan sesuatu pekerjaan, yang bisa berasal dari dalam diri dan juga dari luar" (Dalyono, 2005:55). Motivasi merupakan kondisi psikologis yang memberikan kontribusi besar terhadap seseorang untuk melakukan sesuatu guna mencapai tujuan. Dengan demikian, motivasi dalam proses pembelajaran sangat dibutuhkan agar terjadi percepatan dalam mencapai tujuan pendidikan dan pembelajaran secara khusus. Usaha peningkatan motivasi belajar mahasiswa terkait erat dengan pelaksanaan pembelajaran. Pembelajaran sendiri merupakan suatu proses yang sangat kompleks dan melibatkan berbagai aspek yang saling berkaitan, seperti pengelola pembelajaran (dosen), subjek belajar (mahasiswa), lingkungan belajar (media, model, metode, sarana prasarana dan lain-lain) serta hasil belajar.

Metode pembelajaran merupakan cara yang digunakan dosen untuk mengimplementasikan rencana yang sudah disusun dalam bentuk kegiatan nyata dan praktis untuk mencapai tujuan pembelajaran. Pemilihan metode sangat berpengaruh terhadap keberhasilan pembelajaran karena metode yang kurang tepat akan menjadikan pembelajaran seperti sebuah pemaksaan, monoton, membosankan dan materi tidak tersampaikan dengan baik.

Oleh karena itu, diperlukan upaya untuk meningkatkan motivasi belajar mahasiswa. Salah satu hal yang dapat dilakukan adalah dengan menerapkan model pembelajaran yang menuntut partisipasi aktif mahasiswa. Salah satu model pembelajaran yang dapat diterapkan adalah pembelajaran kooperatif. Model ini dikembangkan untuk mencapai minimal 3 tujuan penting dalam pembelajaran, yaitu hasil belajar akademis, toleransi dan penerimaan terhadap keanekarangaman serta pengembangan keterampilan sosial (Arends, 2008). Lebih jauh, Zakaria (2005) menyatakan bahwa pembelajaran kooperatif menciptakan kesempatan yang luas bagi mahasiswa agar terlibat dalam penyelesaian masalah dengan bekerjasama dalam suatu tim atau kelompok.

Pembelajaran kooperatif memberikan kesempatan untuk saling ketergantungan positif di antara mahasiswa dalam mencapai tujuan pembelajaran. Setiap mahasiswa mempunyai kesempatan yang sama untuk sukses. Aktivitas belajar yang berpusat pada mahasiswa dalam bentuk diskusi, mengerjakan tugas bersama, saling membantu dan saling mendukung dalam memecahkan masalah. Melalui interaksi belajar yang efektif diharapkan mahasiswa akan lebih termotivasi, percaya diri, tidak malu-malu, mampu menggunakan strategi berpikir tingkat tinggi, serta mampu membangun hubungan interpersonal.

Bila ditinjau dari model pembelajaran yang diharapkan, maka model pembelajaran yang memiliki sifat dan karakter tersebut di atas adalah metode problem based learning (PBL) atau sering disebut dengan pembelajaran berbasis masalah dan model pembelajaran Jigsaw. Kedua model pembelajaran ini sangat cocok diterapkan dalam meningkatkan aktivitas dan motivasi mahasiswa dalam belajar. Dari uraian di atas, penulis ingin mengetahui mana metode pembelajaran kooperatif yang paling efektif dalam meningkatkan aktivitas dan motivasi belajar mahasiswa pada perkuliahan Statistik serta mengetahui profil hasil belajar kognitif mahasiswa. 


\section{METODE}

Penelitian ini dilaksanakan di lingkungan Program Studi Pendidikan Guru Sekolah Dasar (PGSD) Universitas Katolik Santo Thomas Sumatera Utara pada semester ganjil tahun ajaran 2016/2017 dengan subjek dalam penelitian ini adalah mahasiswa Prodi PGSD semester 5 yang mengambil mata kuliah Statistika sejumlah 35 mahasiswa. Metode dalam penelitian ini adalah Penelitian Tindakan Kelas (PTK). Penelitian ini direncanakan dan dilaksanakan dalam 2 siklus, dengan penerapan metode-metode dalam pembelajaran kooperatif. Siklus pertama dilaksanakan dengan pembelajaran kooperatif berbasis masalah (PBM). Pada siklus kedua diterapkan metode Jigsaw. Langkah-langkah penelitian yang akan dilaksanakan mengacu pada model Kemmis dan McTaggart. Komponen model penelitian Kemmis dan McTaggart adalah perencanaan, tindakan, pengamatan dan refleksi (Sukardi, 2007).

Subjek dalam penelitian ini adalah mahasiswa prodi pendidikan PGSD semester 5 tahun ajaran 2016/2017 yang mengambil matakuliah Statistik yang berjumlah 35 mahasiswa. Instrumen yang digunakan untuk pengumpulan data penelitian meliputi; (1) Lembar observasi keterlaksanaan pembelajaran; (2) Lembar observasi aktivitas mahasiswa dalam pembelajaran dengan penilaian aspek oral activities, visual activities, listening activities, writing activities dan emotional activities; (3) Lembar observasi efektivitas kelompok dengan penilaian pada aspek efisiensi pemecahan masalah dan partisipasi anggota; (4) angket motivasi untuk mengetahui sejauh mana pembelajaran mampu meningkatkan motivasi belajar mahasiswa, dilihat dari persepsi mahasiswa dengan aspek yang dikaji minat belajar serta kenyamanan dan kepuasan mahasiswa dalam pembelajaran.

Teknik pengumpulan data yang digunakan, yaitu teknik observasi. Teknik observasi digunakan untuk mengungkap aktivitas, efektivitas kelompok dan motivasi mahasiswa. Data yang diperoleh kemudian dianalisis secara deskriptif, dengan menentukan rata-rata hitung aktivitas dan minat mahasiswa kemudian dikategorikan dengan ketentuan pada Tabel 1 (Widoyoko, 2009). Data yang diperoleh berupa skor penilaian setiap mahasiswa yang akan dikonversi menjadi nilai.

Tabel 1. Kriteria Kategori Penilaian

\begin{tabular}{ll}
\hline \multicolumn{1}{c}{ Kategori } & \multicolumn{1}{c}{ Rentang Skor } \\
\hline $\mathrm{SB}$ (Sangat Baik) & Rerata skor $>\mathrm{Mi}+1,6 \mathrm{SBi}$ \\
\hline $\mathrm{B}($ Baik) & $\mathrm{Mi}+0,8 \mathrm{SBi}<$ rerata skor $\leq \mathrm{Mi}+1,6 \mathrm{SBi}$ \\
\hline $\mathrm{C}($ Cukup) & $\mathrm{Mi}-0,8 \mathrm{SBi}<$ rerata skor $\leq \mathrm{Mi}+0,8 \mathrm{SBi}$ \\
\hline $\mathrm{K}$ (Kurang) & $\mathrm{Mi}-1,6 \mathrm{SBi}<$ rerata skor $\leq \mathrm{Mi}-0,8 \mathrm{SBi}$ \\
\hline SK (Sangat Kurang) & Rerata skor $\leq \mathrm{Mi}-1,6 \mathrm{SBi}$ \\
\hline
\end{tabular}

\section{HASIL DAN PEMBAHASAN}

Penelitian ini dilaksanakan pada mata kuliah statistik di Program Studi Pendidikan Guru Sekolah Dasar (PGSD) yakni tentang penerapan dua model pembelajaran kooperatif. Penelitian ini menggunakan PTK (Penelitian Tindakan Kelas), dimana dilaksanakan dalam 2 siklus. Siklus pertama menggunakan model pembelajaran PBM (Pembelajaran Berbasis Masalah) dan pada siklus kedua menggunakan model Pembelajaran Jigsaw. Materi pada siklus pertama tentang regresi berganda dan materi pada siklus kedua tentang regresi linier sederhana.

Tindakan Pada Siklus 1

a. Tahap Perencanaan

Pada tahap ini merupakan tahapan orientasi, yakni mengumpulkan serta menyusun perangkat pembelajaran seperti RPP yang disesuaikan dengan model pembelajaran PBM. 
Pada tahap selanjutnya membentuk kelompok yang terdiri dari mahasiswa yang berkemampuan heterogen, yaitu dari 35 mahasiswa dibentuk menjadi 7 kelompok.

b. Implementasi Tindakan

Pada tahap ini diawali dengan penyampaian tujuan dan gambaran jalannya proses pembelajaran yang akan dilaksanakan. Pada tahapan ini dilaksanakan proses pembelajaran sesuai dengan sintak model pembelajaran PBM.

1. Orientasi peserta didik kepada masalah

Pada tahap ini dosen menjelaskan tujuan pembelajaran, menjelaskan logistik yang diperlukan, pengajuan masalah, memotivasi peserta didik agar terlibat dalam aktivitas pemecahan masalah yang dipilihnya.

2. Mengorganisasikan peserta didik untuk belajar

Pada tahap ini dosen membantu peserta didik/mahasiswa mendefenisikan dan mengorganisasikan tugas belajar yang berhubungan dengan masalah tersebut.

3. Membimbing penyelidikan individual maupun kelompok

Pada tahap ini dosen mendorong mahasiswa untuk mengumpulkan informasi yang sesuai, melaksanakan eksperimen, untuk mendapat penjelasan pemecahan masalah.

4. Mengembangkan dan menyajikan hasil karya

Pada tahap ini dosen membantu mahasiswa dalam merencanakan dan menyiapkan karya yang sesuai seperti laporan, video, model dan membantu mereka untuk berbagai tugas dengan kelompoknya.

5. Menganalisa dan mengevaluasi proses pemecahan masalah

Dosen membantu mahasiswa melakukan refleksi atau evaluasi terhadap penyelidikan mereka dalam proses-proses yang mereka gunakan.

c. Pengamatan

Pada tahap ini dilakukan pengamatan terhadap proses dan dampak tindakan.

1. Pengamatan terhadap proses tindakan

Pada proses pengamatan tindakan ini ditekankan pada aspek aktivitas mahasiswa selama pembelajaran berlangsung, yakni efektivitas kelompok pada model pembelajaran PBM. Pada tabel 4.1 berikut menunjukkan bahwa rata-rata skor aktivitas mahasiswa hasil observasi pada siklus 1 dengan penerapan model pembelajaran PBM.

Tabel 2. Kriteria Aktivitas Mahasiswa Pada Siklus 1

\begin{tabular}{cccc}
\hline No & Kriteria Motivasi & Jumlah Mahasiswa & Persentase \\
\hline 1 & Sangat Tinggi & 1 & $2,86 \%$ \\
\hline 2 & Tinggi & 14 & $40 \%$ \\
\hline 3 & Sedang & 17 & $48,57 \%$ \\
\hline 4 & Rendah & 3 & $8,57 \%$ \\
\hline 5 & Sangat Rendah & 0 & $0 \%$ \\
\hline \multicolumn{2}{c}{ Total } & $\mathbf{3 5}$ & $\mathbf{1 0 0 \%}$ \\
\hline
\end{tabular}

Tabel 3. Kriteria Efektivitas Kelompok Siklus 1

\begin{tabular}{clcc}
\hline No & \multicolumn{1}{c}{ Aspek Aktivitas } & Rerata Skor & Kriteria \\
\hline 1 & Visual Activities & 10,45 & Baik \\
\hline 2 & Oral Activities & 12,85 & Baik \\
\hline 3 & Listening Activities & 4,05 & Sangat Baik \\
\hline 4 & Writing Activities & 11,34 & Baik \\
\hline 5 & Emotional Activities & 11,15 & Baik \\
\hline \multicolumn{2}{c}{ Total } & $\mathbf{4 9 , 8 4}$ & \\
\hline
\end{tabular}


Tabel 4. Kriteria Keterlaksanaan Pembelajaran pada Siklus 1

\begin{tabular}{clcc}
\hline No & Aspek Pembelajaran & Rerata Skor & Kriteria \\
\hline 1 & Pendahuluan & 13,25 & Sangat Baik \\
\hline 2 & Kegiatan Inti & 33,46 & Sangat Baik \\
\hline 3 & Penutup & 5,0 & Sangat Baik \\
\hline & Total & $\mathbf{5 1 , 7 1}$ & Sangat Baik \\
\hline
\end{tabular}

Pengamatan Terhadap Dampak Tindakan

Dampak tindakan ini diamati dari proses pembelajaran yang sedang berlangsung, yakni pada model pembelajaran PBM. Penerapan model ini menuntut setiap mahasiswa terlibat dalam permasalahan yang dipilihnya. Dimana, setiap mahasiswa mampu bereksperimen terhadap permasalahan yang disajikan kepada mereka baik secara individu maupun secara kelompok. Setiap mahasiswa juga dituntut mampu berorientasi dengan teman sekelompoknya dan berdiskusi memecahkan permasalahan dalam kelompok. Hal lain yang penting selama proses pembelajaran berlangsung adalah setiap mahasiswa harus mampu bertanggung jawab secara individu maupun kelompok terhadap hasil dari setiap permasalahan yang dipelajari pada saat perkuliahan berlangsung. Hasil tindakan mereka dikaitkan dengan motivasi belajar dan hasil belajar mahasiswa. Tabel berikut merupakan hasil dari masing-masing tindakan tersebut.

Tabel 5. Ringkasan Kategori Motivasi Belajar Mahasiswa Pada Siklus 1

\begin{tabular}{ccccc}
\hline No & Nilai & Kriteria & Jumlah Mahasiswa & Persentase \\
\hline 1 & $80-100$ & Sangat Baik & 2 & 5,71 \\
\hline 2 & $65-79$ & Baik & 12 & 34,29 \\
\hline 3 & $55-64$ & Cukup & 13 & 37,14 \\
\hline 4 & $0-54$ & Kurang & 8 & 22,86 \\
\hline \multicolumn{7}{r}{ Total } & & $\mathbf{3 5}$ & $\mathbf{1 0 0 \%}$ \\
\hline
\end{tabular}

\section{d. Refleksi}

Pada tahap ini dilakukan penilaian terhadap proses yang telah berlangsung selama proses pembelajaran dan segala tindakan yang telah dilakukan pada tahap sebelumnya. Refleksi pada saat diskusi dilihat apakah ada peningkatan aktivitas dan motivasi mahasiswa dengan model pembelajaran PBM dan segala permasalahan yang timbul di kelas. Dengan demikian dapat ditemukan solusi atau startegi pemecahannya supaya pada tindakan berikutnya dapat diperbaiki pada siklus selanjutnya. Refleksi dilakukan secara kolaboratif yaitu; antara dosen, observer dan mahasiswa. Berikut merupakan hasil refleksi pada siklus I:

1. Dari hasil pengamatan pada kelompok mahasiswa selama proses pembelajaran berlangsung terdapat beberapa mahasiswa yang kurang cocok dengan teman sekelompoknya sehingga membuat beberapa mahasiswa memilih untuk diam.

2. Pada pengamatan terhadap aktivitas mahasiswa, aktivitas yang sangat baik terdapat pada listening activities. Mahasiswa hanya mampu mendengarkan penjelaskan dosen pada saat dosen melakukan pengarahan dan membimbing menemukan solusi dari setiap permasalahan yang diberikan kepada mahasiswa.

3. Hasil pada aspek motivasi juga belum dapat dikatakan baik, walau ada 12 mahasiswa yang memperoleh nilai dengan kriteria baik atau 34,29\% dan 2 mahasiswa memperoleh kriteria cukup baik atau $5,71 \%$. Namun jika dibandingkan dengan keseluruhan total mahasiswa yang berjumlah 35 orang belum dapat dikatakan mewakili setengah dari total jumlah mahasiswa yang ada.

4. Pada aspek keterlaksaan pembelajaran ditunjukkan bahwa dari hasil observasi diperoleh skor yang tinggi yakni berada pada kriteria sangat baik. Ini menunjukkan 
bahwa tahapan-tahapan pembelajaran dengan model pembelajaran PBM sudah berjalan dengan baik sesuai langkah-langkah pembelajaran tersebut.

Pada tahap refleksi ini akan memberikan gambaran dan tindakan apa saja yang dilakukan untuk memperbaiki kesalahan dan kekurangan pada siklus 2. Pada siklus 2 ditentukan model pembelajaran kooperatif lain yang mampu mengurangi atau mengatasi permasalahan yang terjadi pada siklus sebelumnya. Pada dasarnya model pembelajaran kooperatif memiliki kelebihan masing-masing dan aspek apa yang menjadi orientasi perbaikan.

Tindakan Pada Siklus 2

Jika diperhatikan dari hasil refleksi pada siklus 1 maka model pembelajaran Jigsaw diharapkan mampu memperbaiki kekurangan pada model sebelumnya (Model PBM). Hal apa saja yang perlu diperhatikan agar model Jigsaw dapat meningkatkan aktivitas dan motivasi mahasiswa.

a. Perencanaan

Pada siklus ini, perencanaan merupakan tahap awal yang dilakukan untuk mengorientasi mahasiswa yang sudah tertuang pada RPP dengan model pembelajaran Jigsaw. Pada model pembelajaran ini mahasiswa dibagi dalam kelompok asal dan kelompok ahli. Kelompok asal terdiri dari 7 kelompok dengan jumlah mahasiswa setiap kelompok adalah 5 orang. Pada siklus ini pembagian kelompok memperhatikan jenis kelamin dan kemampuan mahasiswa berdasarkan siklus sebelumnya yaitu siklus 1 . Kelompok ahli ditentukan dari kelompok asal. Pada siklus 2 ini, kelompok ahli terdiri dari 5 kelompok dan bertugas untuk membahas dan menyelesaikan masalah dari tema tertentu dalam Statistika.

b. Implementasi Tindakan

Pada tahap ini, tujuan dan gambaran pembelajaran disampaikan oleh dosen. Kemudian bersama-sama dengan para mahasiswa melaksanakan pembelajaran berdasarkan sintak atau langkah-langkah dari model pembelajaran Jigsaw. Berikut adalah langkahlangkah dari model pembelajaran Jigsaw:

1) Tahap Reading

Pada tahap reading (membaca), mahasiswa diberi tugas untuk membaca dan memahami topik atau materi yang berbeda pada tiap-tiap kelompok.

2) Tahap Expert Group Discussion

Pada tahap Expert Group Discussion (diskusi kelompok ahli), mahasiswa pada kelompok asal yang menerima materi yang sama dikumpulkan dalam kelompok ahli. Mahasiswa yang sudah tergabung dalam kelompok ahli ini mendiskusikan topik atau materi yang telah mereka baca sebelumnya.

3) Tahap Team Report

Tahap ini dikatakan juga tahap laporan kelompok dimana para ahli yang telah mendiskusikan materi secara bersama-sama memutuskan dan menyesepakati jawaban dari masalah yang telah mereka bahas. Kemudian, kembali ke kelompok asal masingmasing.

4) Tahap Test

Tahap Test atau disebut juga tahap latihan soal ini dilaksanakan oleh mahasiswa secara individu. Hal ini dilakukan untuk melihat sejauh mana penguasaan mahasiswa terhadap materi yang telah dipelajari. Soal dalam tahap ini adalah semua materi yang telah dibahas dan dipelajari selama masa siklus 2.

5) Tahap Team Recognition

Pada tahap team recognition (penghargaan kelompok), dosen memberikan penghargaaan pada setiap kelompok yang mendapatkan nilai yang sangat baik atau skor tertinggi. Hal ini mencakup pada skor evaluasi dan skor efektivitas kelompok. 


\section{c. Pengamatan}

Tahap pengamatan dilakukan selama proses pembelajaran dan terhadap proses tindakan di kelas. Tindakan yang dilakukan diamati dari segi akibat yang terjadi dari proses itu sendiri. Sejauh mana tindakan itu mempengaruhi hasil capaian dan jutuan yang telah direncanakan.

Tabel 6. Kriteria Aktivitas Mahasiswa pada Siklus 2

\begin{tabular}{clcc}
\hline No & Kategori Motivasi & Jumlah Mahasiswa & Presentase \\
\hline 1 & Sangat Tinggi & 7 & $20 \%$ \\
\hline 2 & Tinggi & 27 & $77,14 \%$ \\
\hline 3 & Sedang & 1 & $2,86 \%$ \\
\hline 4 & Rendah & 0 & $0 \%$ \\
\hline 5 & Sangat Rendah & 0 & $0 \%$ \\
\hline & Total & $\mathbf{3 5}$ & $\mathbf{1 0 0 \%}$ \\
\hline
\end{tabular}

Tabel 7. Kriteria Efektivitas Kelompok Pada Siklus 2

\begin{tabular}{clcc}
\hline No & Aspek Aktivitas & Rerata Skor & Kriteria \\
\hline 1 & Visual Activities & 14,23 & Sangat Baik \\
\hline 2 & Oral Activities & 16,9 & Sangat Baik \\
\hline 3 & Listening Activities & 4,75 & Sangat Baik \\
\hline 4 & Writing Activities & 13,00 & Sangat Baik \\
\hline 5 & Emotional Activities & 14,32 & Sangat Baik \\
\hline \multicolumn{4}{c}{ Total } \\
\hline
\end{tabular}

Tabel 8. Kriteria Keterlaksaan Pembelajaran Siklus 2

\begin{tabular}{clcc}
\hline No & Aspek Pembelajaran & Rerata Skor & Kriteria \\
\hline 1 & Pendahuluan & 15,65 & Sangat Baik \\
\hline 2 & Kegiatan Inti & 34,42 & Sangat Baik \\
\hline 3 & Penutup & 4,46 & Sangat Baik \\
\hline & Total & 54,53 & Sangat Baik
\end{tabular}

Dampak dari tindakan pada siklus 2 dapat diamati dari proses pembelajaran yang berlangsung di kelas. Bila dikaji lebih dalam maka hasil tindakan yang diberikan tentang motivasi belajar dan hasil belajar mahasiswa pada siklus 2 jauh lebih baik dari siklus sebelumya.

d. Refleksi

Tahap ini adalah tahap dimana dosen, mahasiswa dan observer melakukan kolaborasi untuk memdapatkan saran atau masukan tentang pelaksanaa pada siklus 2. Di bawah ini merupakan refleksi siklus 2:

1) Aktivitas Mahasiswa pada kategori motivasi tinggi memperoleh persentase sebesar $77,14 \%$ dan kategori sangat tinggi sebesar $20 \%$. Hal ini menunjukkan bahwa pada siklus ini mahasiswa memiliki motivasi tinggi.

2) Efektivitas setiap kelompok dalam memecahkan masalah dan pemerataan partisipasi mahasiswa sangat baik

3) Berdasarkan keterlaksaan pembelajaran dengan model Jigsaw menunjukkan bahwa pada siklus ini semua tahapan berada pada kategori sangat baik.

Efektifitas Pembelajaran Kooperatif Ditinjau dari Aspek Aktivitas Belajar Mahasiswa Aspek yang pertama kali dikaji dalam penelitian ini adalah bagaimana dampak penerapan suatu model pembelajaran kooperatif terhadap aktivitas mahasiswa, ditinjau dari aktivitas individu maupun aktivitas kelompok. Dalam penelitian ini, model pembelajaran 
yang digunakan pertama adalah model pembelajaran berbasis masalah yang berbasis pada adanya masalah. Model pembelajaran kedua yang digunakan adalah model pembelajaran Jigsaw yang ditentukan berdasarkan hasil refleksi siklus pertama.

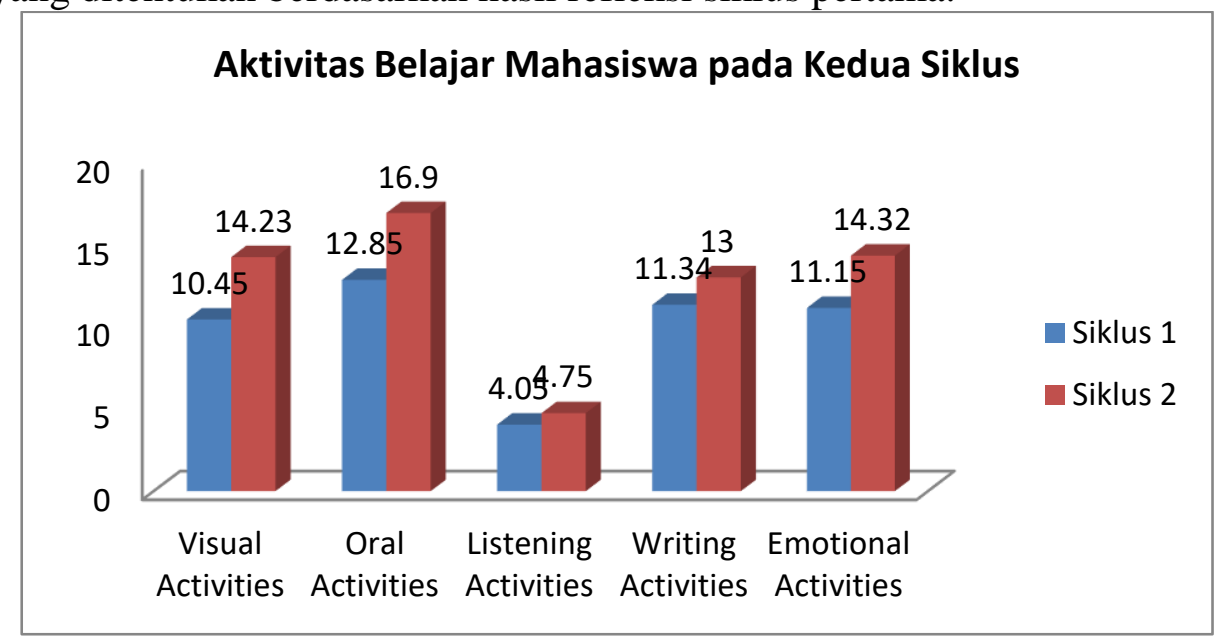

Gambar 1. Perbandingan Aktivitas Belajar Mahasiswa pada Siklus 1 dan 2

Berdasarkan gambar 1 di atas nampak semua aktivitas belajar mahasiswa pada siklus 2 lebih baik dari pada siklus 1. Pada siklus 1 dengan model pembelajaran PBM aktivitas yang memiliki skor paling tinggi adalah Listening Activities dengan kriteria sangat baik. Pada tahap ini, aktivitas yang dilakukan oleh mahasiswa adalah mendengarkan penjelasan dosen atas materi yang disampaikan kemudian mahasiswa melakukan diskusi. Skor pada listening activities tinggi diakibatkan oleh pasifnya mahasiswa terhadap pembelajaran dan hanya melakukan aktivitas mendengar. Aktivitas mendengar tidak membutuhkan kemamuan berfikir yang kompleks layaknya emotional activities dan writing activities.

Dari hasil siklus 1 dengan penerapan model pembelajaran PBM dapat dilihat bahwa belum maksimalnya aktivitas mahasiswa dalam pembelajaran. Hal ini diharapkan dapat diperbaiki pada kegiatan pembelajaran dengan model jigsaw pada siklus 2 dalam meningkatakan aktivitas belajar mahasiswa.

Efektifitas Pembelajaran Kooperatif Ditinjau dari Aspek Motivasi Belajar Mahasiswa

Selain aspek aktivitas yang menjadi kajian pada penelitian ini, aspek motivasi belajar mahasiswa juga dilihat dan dikaji sebagai bagian dari pembelajaran yang diterapkan. Gambar 2 merupakan sajian yang berhubungan dengan motivasi belajar pada siklus 1 dan siklus 2. Siklus 1 diberikan model pembelajaran PBM dan siklus 2 menggunakan model pembelajaran Jigsaw. Jika diperhatikan gambar grafik tersebut dapat dijelaskan bahwa peningkatan aspek motivasi belajar mahasiswa kategori sangat tinggi pada siklus 1 menjadi 7 orang (20\%) pada siklus 2. Demikian juga pada kategori tinggi yang tadinya 14 orang (40\%) menjadi 27 orang $(77,14 \%)$. Terlihat bahwa terjadi peningkatan motivasi belajar pada model pembelajaran Jigsaw yang diterapkan pada siklus 2 .

Adapun efek peningkatan ini terjadi akibat beberapa hal yakni faktor interaksi yang terbuka yang membuat komunikasi antar mahasiswa menjadi lebih baik. Faktor lain adalah latihan yang bermakna yang terjadi dalam kelompok asal dan kelomok ahli. Model pada siklus 2 ini juga memfasilitasi mahasiswa menjalin interaksi sebebas-bebasnya dan hal ini menantang bagi setiap mahasiswa dalam menyelesaikan tugas yang diembannya. 


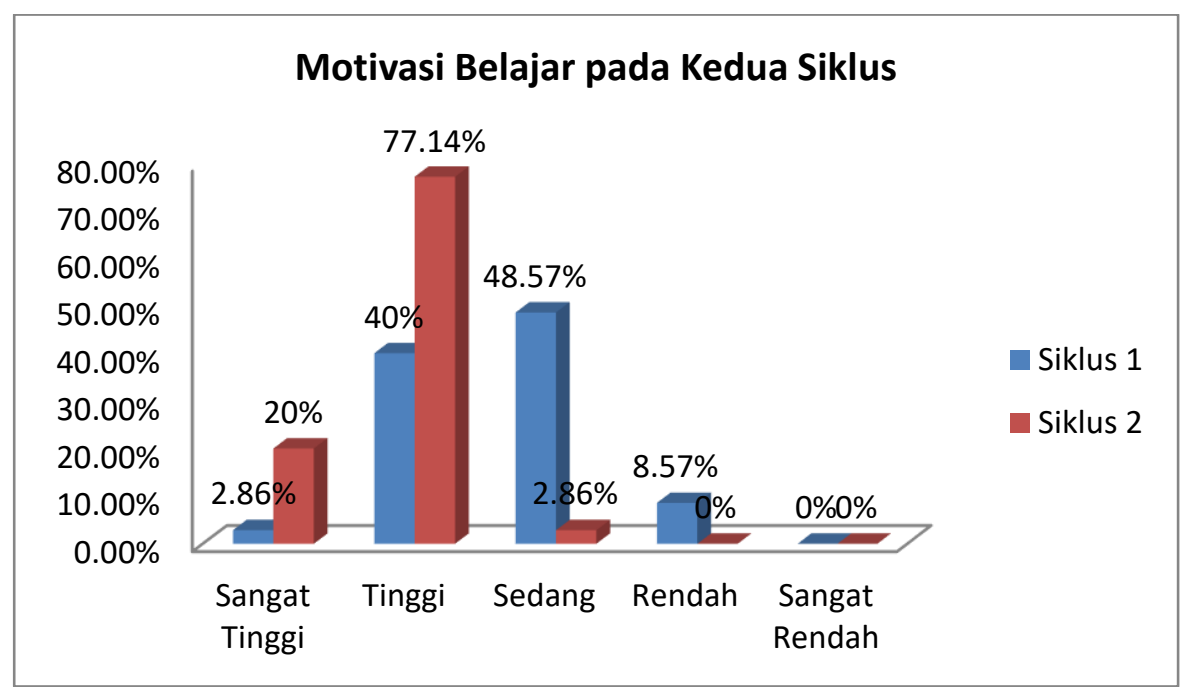

Gambar 2. Perbandingan Motivasi Belajar Mahasiswa pada Siklus 1 dan Siklus 2

Pada gambar 2 di atas terlihat bahwa kelima aspek pada motivasi belajar didominasi oleh siklus 2, yang artinya terjadi peningkatan motivasi kearah yang lebih baik selama model pembelajaran Jigsaw. Pada kategori "sedang" menurun jumlah mahasiswa yang motivasinya pada siklus 1 jumlahnya cukup signifikan, dan pada kategori rendah menjadi $0 \%$ pada siklus 2 .

Hasil Belajar Kognitif Mahasiswa dengan Penerapan Model PBM dan Jigsaw

Model pembelajaran PBM dan Jigsaw yang diterapkan pada penelitian ini memberikan dampak yang berbeda pada hasil belajar kognitif mahasiswa. Pada model pembelajaran PBM yang diterapkan di siklus 1 memberikan hasil bahwa ada 1 kelompok yang mendapat kriteria kurang, 4 kelompok yang memiliki kriteria cukup, dan 2 kelompok yang mendapat kriteria baik. Rerata efesiensi pemecahan masalah setiap kelompok 17,43 dengan kategori cukup. Sedangkan, rerata partisipasi anggota adalah 13 dengan kategori cukup. Pada model pembelajaran Jigsaw semua kelompok mendapat kategori baik. Rerata efesiensi pemecahan masalah setiap kelompok adalah 20,8 dengan kategori baik dan rerata partisipasi anggota setiap kelompok adalah 18,2 dengan kategorin baik.

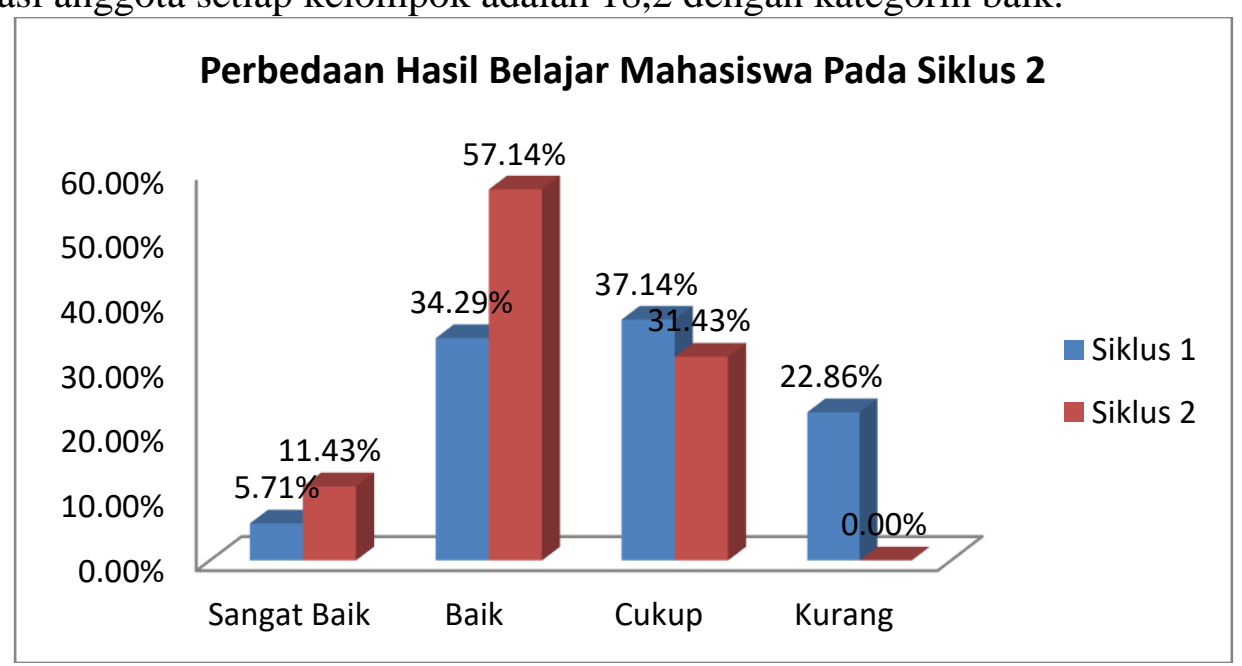

Gambar 3. Perbedaan Hasil Belajar Kognitif pada Kedua Siklus

Berdasarkan gambar 3 di atas, dapat dijelaskan bahwa terjadi peningkatan dari siklus 1 ke siklus 2. Pada siklus 1 kriteria "kurang" terdapat 22,86\% sedangkan pada siklus 2 tidak ada mahasiswa yang mendapat kategori kurang. Hal ini menyatakan bahwa ada peningkatan yang terjadi pada siklus 2. Pada kriteria "cukup" terjadi penurunan jumlah 
mahasiswa dari $37,14 \%$ pada siklus 1 menjadi $31,43 \%$ pada siklus 2 . Demikian juga pada kategori baik dan sangat baik terjadi peningkatan dari siklus 1 ke siklus 2 masing-masing $34,29 \%$ menjadi $57,14 \%$ dan $5,71 \%$ menjadi $11,43 \%$.

\section{KESIMPULAN}

Berdasarkan hasil penelitian dan pembahasan, maka didapat beberapa kesimpulan yakni: 1) Aktivitas mahasiswa pada model pembelajaran Jigsaw (Siklus 2) lebih baik dari pada aktivitas mahasiswa pada model pembelajaran PBM (Siklus 1); 2) Motivasi belajar mahasiswa pada model pembelajaran Jigsaw (Siklus 2) lebih baik atau ada peningkatan dari model pembelajaran PBM (Siklus 1); dan 3) Penerapan pembelajaran model kooperatif tipe Jigsaw lebih efektif dalam meningkatkan aktivitas dan motivasi belajar mahasiswa jika dibandingkan dengan penerapan model pembelajaran PBM.

\section{DAFTAR PUSTAKA}

Arends, R. I. 2008. Learning To Teach. Yogyakarta: Pustaka Pelajar.

Zakaria, E., Iksan, Z. 2007. Promoting Cooperative Learning in Science and Mathematics, Education: A Malaysian Perspective. Eurasia Journal of Mathematics, Science \& Technology Education, 3(1), 35-39.

Widoyoko, E. P. 2009. Evaluasi Program Pembelajaran. Yogyakarta: Pustaka Pelajar.

Partana, C. F. 2008. Kajian Efektivitas Penerapan Metode Pembelajaran Kooperatif Tipe Jigsaw dan STAD pada Mata pelajaran IPA Aspek Kimia di SMP 2 Mlati. Cakrawala Pendidikan, 27(2).

Uno, H. B. 2007. Model Pembelajaran. Jakarta: Bumi Aksara

Slavin, R. E. 2009. Cooperative Learning. Bandung: Nusa Media. Terjemahan. Buku Asli terbit tahun 2005.

Slis, D. F. 2005. Assesment of the use of the Jigsaw Method and Active Learning in Nonmajors, Introductory Biology. Bioscene. 31(4).

Sudarwan, D. 2004. Motivasi Kepemimpinan dan Efektivitas Kelompok. Jakarta: Rineka Cipta.

Sugianto. 2010. Model-model Pembelajaran Inovatif. Surakarta: Yuma Pustaka.

Sukardi. 2007. Metodologi Penelitian Pendidikan, Kompetensi dan Praktiknya. Jakarta: Bumi Aksara.

Sipayung, T. N, dan Simanjuntak, S. D. 2017. Modul Pembelajaran Matematika. Bandung: Batic Press. (Tersedia di https://osf.io/preprints/inarxiv/2xn3w/).

Zaini, H., dkk. 2008. Strategi Pembelajaran Aktif. Yogyakarta: Pustaka Insan Madani. 